\title{
PENDEKATAN PEMBELAJARAN ANAK AUTIS DENGAN MENGGUNAKAN METODE FLOOR TIME DI SEKOLAH DASAR KEC.SITUBONDO KABUPATEN SITUBONDO
}

\author{
Amalia Risqi Puspitaningtyas*, Vidya Pratiwi \\ Program Studi Pendidikan Guru Sekolah Dasar, Fakultas Keguruan dan Ilmu Pendidikan, \\ Universitas Abdurachman Saleh Situbondo, Indonesia \\ *Korespondensi. E-mail: amaliarisqipuspitaningtyas@gmail.com
}

\begin{abstract}
Abstrak
Dalam penelitian ini ingin mengetahui dan menjelaskan pendekatan pembelajaran bagi anak autis, karena dalam menghadapi anak autis di kelas terutama ketidaklancaran terdapat keterbatasan kemampuan berkomunikasi antara anak autis dan guru serta teman- teman sekelasnya. Autis memiliki gangguan perkembangan dengan ciri- ciri yang tampak mencakup bahasa, komunikasi dan perilaku ritualistik/stereotip. Dalam mengatasai keterbatasan kemampuan komunikasi pada anak autis, beberapa ahli mengembangan pendekatan pembelajaran, salah satunya adalah metode floor time. Dalam metode ini lebih mengedepankan bermaian yang berlandaskan pada ikatan relasi dan lebih difokuskan pada minat anak. Penelitian ini menggunakan penelitian deskriptif kualititatif dengan pendekatan metode floor time, subyek penelitian ini anak autis yang ada di Sekolah dasar yaitu 2 siswa autis di SDN 6 Dawuhan dan 1 siswa autis di SD Muhammadiyah Kabupaten Situbondo.Hasil penelitian pendekatan pembelajaran dengan metode floor time yang mencakup 5 strategi yang diterapkan oleh guru banyak membuahkan hasil perkembangan-perkembangan yang di miliki oleh siswa autis.Berdasarkan pada hasil observasi dan wawancara dengan guru kelas di SDN 6 Dawuhan dan SD Muhammdiyah ditemukan bahwa dalam penerapan metode floor time kemampuan verbal anak autis meningkat yaitu subjek dalam komunikasi yang ditandai dengan beberapa perkembangan yaitu yang menitik beratkan dalam interaksi antara subjek dengan guru dan lingkungann sekitarnya sehingga dalam proses pembelajaran subjek sudah lumayan jelas dan kemampuan dalam menulis sudah baik hanya saja butuh berualang kali dalam memberikan pemahaman dan arahan dalam menyelesaikan tugas sekolah, walaupun dalam memahami bahasa tulis masih memerlukan bimbingan. Tidak hanya guru kelas yeng menerapkan metode tersebut tetapi orang tua Subjek sudah menerapkan metode floor time yang didalam penerapannya lebih kepada komunikasi dan interaksi. Hasil dari penerapan metode floor time yang diterapkan oleh orang tua Subjek membuahkan hasil dalam perkembangan-perkembangan emosi, komunikasi dan interaksi saat berada dirumah.
\end{abstract}

Kata Kunci: Anak Autis, Metode Floor Time

\section{TEACHING CHILDREN WITH AUTISM BY IMPLEMENTING FLOOR TIME METHOD AT ELEMENTARY SCHOOLS IN SITUBONDO}

\begin{abstract}
In this study want to find out and explain the learning approach for children with autism, because in dealing with autistic children in the classroom, especially the lack of fluency in the teaching and learning process there is a limited ability to communicate between autistic children and teachers and friends. Autism is a disorder with characteristics that appear in language, communication and ritualistic / stereotypical behavior. In overcoming the limitations of communication skills in children with autism, some experts develop learning approaches, one of which is the floor time method. Approach in an interactive way or playing with children based on bonding relationships and interesting to
\end{abstract}




\section{Jurnal Riset Pendidikan Dasar, 01 (1), Oktober 2018 (78-83)}

Amalia Risqi Puspitaningtyas, Vidya Pratiwi

children's interests. This study uses qualitative research methods using the floor time method, the subject of this study on elementary school students in SDN 6 Dawuhan and 1 autistic child in Muhammadiyah Elementary School, Situbondo Regency. The results of the study approach to the floor time method that includes the 5 strategies applied by the teacher produced a lot of results of the development processes that occur in autistic students. Based on the results and interviews with classroom teachers at SDN 6 Dawuhan and SD Muhammdiyah found that in the time system can increase verbal ability of children with autism is the subject in communication based on several developments that focus on the interaction between the subject and the teacher in the subject learning process is quite clear and the ability in writing is good just need time to provide understanding and direction in the context of school work, although in the comfort of writing. Not only the class teacher who decides the method but the subject's parents have used the time method more than the application of communication and interaction. The results of the floor time process that is applied by parents of the subject yield results in developments, communication and disruption while at home.

Keywords: Children with autism, floor time method

\section{PENDAHULUAN}

Anak Berkebutuhan khusus adalah anak yang dalam proses pertumbuhan/ perkembangannya secara signifikan mengalami kelainan/penyimpangan (fisik, mental, intelektual, sosial, emosi, emosional) dibandingkan anak-anak lain seusianya sehingga mereka memerlukan pelayanan pendidikan secara khusus. Anak berkebutuhan khusus memiliki karakteristik yang berbedabeda, berdasarkan kelainan yang mereka miliki, salah satunya adalah anak autis.Autisme merupakan suatu gangguan perkembangan, gangguan pemahaman atau gangguan fungsi otak yang bersifat pervasif, dan bukan suatu bentuk penyakit mental. Gangguan perkembangan fungsi otak yang bersifat pervasive (inco) yaitu meliputi gangguan kognitif (kemampuan), bahasa, perilaku, komunikasi, dan gangguan interaksi sosial. Autisme atau biasa disebut ASD (Autistic Spectrum Disorder) merupakan gangguan perkembangan fungsi otak yang kompleks dan sangat bervariasi (spectrum). Ganguan ini meliputi cara berkomunikasi, berinteraksi sosial dan kemampuan berimajinasi.

Hal yang mendasar dari anak autis yaitu kesulitan dalam memahami apa yang mereka lihat, dengar, dan mereka rasakan. Sehingga dalam proses belajar mengajar anak autis mengalami hambatan dalam penerimaan materi dari guru. Dalam proses belajar mengajar seorang guru di tuntut untuk bisa memberikan pemhaman terhadap anak autis, karena anak autis memiliki kekurangan dari segi komunikasi serta bersosialisasi. Dalam melakukan interaksi dengan seseorang hal yang harus bisa dipahami pertama yaitu dari bahasa mereka, karena bahasa merupakan komunikasi manusia dalam mengadakan hubungan dengan sesama.

Salah satu pendekatan yang baik untuk anak autis dalam berkomunikasi yaitu pendekatan The Developmental Individual Difference Relationship-Based (DIR) atau lebih dikenal dengan pendekatan floor time. Pendekatan ini dimulai dengan suasana yang menyenangkan dalam menciptakan interaksi dan komunikasi yang berkesinambungan, sehingga anak autis bisa berkomunikasi dengan baik. Pendekatan DIR memiliki landasan pada enam tahap perkembangan yang telah dicapai anak terutama relasi interaktif yang paling mendukung perkembangannya. Salah satu komponen yang ada pada pendekatan DIR yaitu pendekatan Floor time. Metode Floor time yaitu berfokus dalam penciptaan interaksi pembelajaran yang bermakna secara emosional sehingga anak belajar menguasai kemampuan yang penting dalam perkembangannya. Dengan metode floor time anak autis dapat berkomunikasi dan berbahasa secara baik, sehingga mereka bisa berinteraksi dengan lingkungannya.

Seseorang dapat dilihat dari segi berbahasanya, karena semakin terampil dalam berbahasa semakin baik interaksi yang terjalin dengan lingkungnya.Keterampilan tersebut 
hanya bisa diperoleh dari praktek dan latihan (Pamuji, 2007: 119). Penguasaan bahasa baik bahasa ekspresif maupun bahasa reseptif penting bagi anak autis agar dapat berkomunikasi, berinteraksi, menyampaikan ide/pikirannya, dan menyesuaikan dengan lingkungannya. Dengan memiliki komunikasi yang baik, anak autis dapat mengikuti pembelajaran di kelas dengan baik pula. Namun salah satu kekurangan anak autis dalam hal berbahasa dan berkomunikasi maka anak autis pun mengalami kesukaran dalam memahami arti kata-kata serta penggunaan bahasa yang sesuai konteksnya (Azwandi, 2005: 15).

\section{METODE}

Penelitian ini menggunakan pendekatan deskriptif kualitatif. Penelitian deskriptif bertujuan untuk menggambarkan secara sistematis, faktual, dan akurat tentang suatu situasi, keadaan, atau bidang kajian yang menjadi obyek penelitian. Subjek Penelitian ini adalah siswa autis yang ada di Sekolah dasar di kabupaten situbondo yaitu terdapat 2 siswa autis di SDN 6 Dawuhan dan 1 siswa autis di SD Muhammadiyah. Dalam memperoleh data menggunakan metode observasi,wawancara dan dokumentasi.

Dalam penelitian ini menggunakan teknik analis data yaitu pengumpulan data, reduksi data, penyajian data dan kesimpulan atau verifikasi. Subjek penelitian anak autis di SDN 6 Dawuhan yaitu JO dan CK, sedangkan subjek penelitian di SDI Muhammadiyah yaitu DK.

\section{HASIL DAN PEMBAHASAN}

\section{a. Hasil}

Dari hasil penelitian dalam penerapan metode floor time dapat meningkatkan kemampuan komunikasi anak autis dalam interaksi di Sekolah Dasar terumata dalam menerima materi pelajaran dari guru dan interaksi dengan lingkungan. Masalah yang sering terjadi adalah para orang tua yang salah menetapkan strategi bagi perkembangan anaknya, orang tua lebih memproritaskan halhal yang bersifat akademik padahal problemantika anak autis adalah komunikasi dan sosialisasi (Handojo, 2003:48) maka diperoleh pembahasan sebagai berikut: Komunikasi verbal adalah komunikasi yang menggunakan kata-kata dalam penyampaian pesan atau informasi (Rusmita, 2011) dilihat dari hasil penelitian subjek sudah mampu mengucapkan kata namun belum dapat menyampaikan pesan maupun informasi Menurut Mirza Maulana (2002 : 203) gangguan komunikasi tersebut dapat terlihat dalam bentuk keterlambatan bicara, tidak bicara, bicara dengan bahasa yang tidak dimengerti (bahasa planet) atau bicara hanya meniru saja (ekolalia), pernyataan ini tentunya sejalan dengan kemampuan komunikasi verbal yang di alami siswa autis yaitu CK dan DK masih sulit mulai berbicara dimana mengalami keterlambatan sehingga mempengaruhi komunikasinya dimana sampai sekarang dan CK dan DK dalam berbahasanya patah-patah dalam berbicara maupun membaca pesan, bahkan ekolalia (hanya meniru) berbeda dengan JO yang menunjukkan kemajuan yang besar yaitu berbicara sudah jelas sudah mampu memahami pertanyaan dari guru meski harus di ulang- ulang dan JO juga sudah berinteraksi dengan teman sekalasnya dengan mengikuti permaianan yang dilakukan teman sekelasnya. Setiap orang memiliki gaya khas dalam berbicara dan mempunyai cara dalam topiktopik yang dibicarakan (Deddy Mulyana, 2011:327), pada kemampuan mengerjakan tugas anak autis yaitu JO bisa melaksanakan tugas dengan lancar dan benar meski perlu adanya pendampingan dari guru, berbeda dengan CK dan DK dalam mengerjakan tugas sekolah masih perlu pendampingan oleh guru karena kalau tidak ada pendampingan dar guru CK dan DK akan sibuk dengan dunianya sendiri atau bermain sehingga tugas sekolahnya tidak dikerjakan. Dari ketiga anak 


\section{Jurnal Riset Pendidikan Dasar, 01 (1), Oktober 2018 (78-83)}

Amalia Risqi Puspitaningtyas, Vidya Pratiwi

autis terlihat bahwa mereka memiliki gaya khas setiap bertemu dengan orang yaitu JO setiap ada orang baru yang memanggilnya pasti bersikap cuek, tetapi ketika di ajak berkomunikasi JO akan menjawabnya dengan tersenyum sedangkan CK dan DK pasti tersenyum namun ketika lawan berbicara mengajak komunikasi $\mathrm{CK}$ hanya diam. America Speech Language Hearing Association (ASLHA) menyatakan ada tiga komponen wicara yaitu 1)artikulasi, 2)suara, 3)kelancaran (Mulyono Abdurrahman, 2003:83), pernyataan ini tentunya sejalan dengan hasil penelitian pada ketiga anak autis dimana JO memiliki kemampuan artikulasi dan kelancaran bicara walaupun suara yang keluar pelan sedangkan $\mathrm{CK}$ dan DK dalam komunikasi masih terkesan patah-patah dan nada suara lemah. Penelitian menunjukan bahwa ketiga anak autis sering melakukan sentuhan berupa menepuk pada orang tertentu itu membuktikan bahwa berusaha melakukan komunikasi.

Dalam penerepan metode floor time lebih menakankan pada interaksi pembelajaran yang bermakna secara emosional dengan menggunakan enam kapasitas perkembangan dasar anak dan dalam metode ini lebih membangun landasan- landasan untuk perkembangan yang sehat meski hanya mengelola 3 perilaku yang tampak. Dengan pendekatan ini JO,CK dan DK sudah dapat berkomunikasi dan berbahasa dengan baik dan bisa berinteraksi dengan lingkungannya. Seseorang dapat dilihat dari segi berbahasanya, karena semakin terampil dalam berbahasa semakin baik interaksi yang terjalin dengan lingkungnya. Keterampilan tersebut hanya bisa diperoleh dari praktek dan latihan (Pamuji, 2007: 119). Penguasaan bahasa baik bahasa ekspresif maupun bahasa reseptif penting bagi anak autis agar dapat berkomunikasi, berinteraksi, menyampaikan ide/pikirannya, dan menyesuaikan dengan lingkungannya. Dengan mempunyai komunikasi dengan baik JO,CK dan DK dapat mengikuti pembelajaran di kelas dengan baik pula. Sehingga dalam penerapan metode floor time membuahkan hasil dalam perkembanganperkembangan subjek yaitu dari segi emosi, komunikasi dan interaksi.

Mehrabian dan Ferris menyebutkan bahwa parabahasa adalah terpenting kedua setelah ekpresi wajah dalam menyampaikan perasaan atau emosi (Deddy Mulyana, 2011:85). Pernyataan ini sejalan dengan hasil penelitian, dimana JO,CK dan DK ketika berkomunikasi cenderung datar tanpa penekanan, kecepatan suaranya pun masih lamban, serta ketepatan dalam merespon masih kurang karena belum bisa fokus dan tidak mudah memahami. Perilaku tentunya mempengaruhi cara orang berinteraksi sosial. Perilaku yang di maksud ini adalah sesuatu yang dikerjakan ,dikatakan, dilihat, dirasakan, dan apa yang kita lakukan sendiri (Prasetyono, 2008:87). Sejalan dengan pernyataan hasil penelitian dimana JO,CK dan DK tidak mengalami gangguan pendengaran namun saat di panggil belum mampu menyahut, ketika salahpun ketiga anak autis belum mampu memiliki inisiatif untuk meminta maaf karena JO,CK dan DK belum dapat membedakan mana yang benar mana salah, perilaku JO dalam mengikuti percakapan sangat baik berbeda deng CK dan DK cenderung pasif atau terkadang justru hanya diam.

Deddy Mulyana (2011:86) menyatakan mereka percaya bahwa kebersamaan, ngobrol, dan kegaduhan adalah tanda kehidupan yang baik, tetapi untuk anak autis mereka cenderung diam bukannya tidak mau tetapi mereka memiliki keterbatasan dalam komunikasi sehingga mempengaruhi perilaku mereka, merespon adalah suatu hal yang sulit untuk JO,CK dan DK karena kelemahan dalam komunikasi sehingga untuk memberikan umpan balik merupakan suatu kelemahan apalagi saat ini JO,CK dan DK baru menguasai komunikai satu arah. Interaksi sosial yang dilakukan JO,CK dan DK mendasari adanya keinginan untuk dimengerti, 
seperti halnya ketika berulang kali memanggil nama teman sebangkunya tetapi ada sahutan JO,CK dan DK hanya diam saja tetapi kemudian memanggil nama lagi, itu menunjukan salah satu kemauan untuk berinteraksi. JO memiliki kemampuan untuk memulai komunikasi dan interaksi sosial berbeda dengan CK dan DK belum memiliki kemampuan untuk memulai komunikasi. Hasil penelitian menunjukan bahwa JO,CK dan DK termasuk dalam klasifikasi anak autis grup pasif karena merupakan jenis anak autis yang tidak berinteraksi secara spontan, dan interaksi dari pihak lain. JO,CK dan DK sudah mampu berbicara tetapi berbicaranya belum bisa digunakan untuk berkomunikasi. Penelitian ini menunjukkan bahwa JO,CK dan DK lebih memperlihatkan komunikasi verbal melalui sentuhan dan gerakan tubuh. Saat ini perkembangan komunikasi dan interaksi subjek sudah cukup baik karena sudah dapat merespon lingkungannya walaupun tidak sepenuhnya hasilnya baik seperti anak-anak lainnya meski mampu berinteraksi selama 7 menit.

\section{b. Pembahasan}

Hasil penelitian yang telah dideskripsikan dalam mengenai pendekatan pembelajran dengan metode floor time dalam meningkatkan kemampuan komunikasi anak autis dalam interaksi sosial di SDN 6 Dawuhan dan SDI Muhammadiyah dapat disimpulkan bahwa dalam penerapan metode floor time yang mencakup 5 strategi yang diterapkan oleh guru sehingga banyak membuahkan hasil perkembanganperkembangan pada siswa autis.Berdasarkan pada hasil wawancara dengan guru kelas di SDN 6 Dawuhan dan SDI Muhammdiyah ditemukan bahwa dalam penerapan metode floor time kemampuan verbal anak autis yaitu JO,CK dan DK dalam bahasa komunikasi yang ditandai dengan beberapa perkembangan yaitu yang menitik beratkan dalam komunikasi sehingga dalam berbicara merekapun sudah lumayan jelas dan kemampuan dalam menulis pun sudah baik hanya saja butuh arahan dalam menyelesaikan tugas sekolah, walaupun dalam memahami bahasa tulis masih memerlukan bimbingan.

Bentuk kemampuan komunikasi yang dapat dilakukan berupa komunikasi satu arah dari peneliti ke JO,CK dan DK karena belum bisa fokus terhadap sumber suara. JO,CK dan DK sudah bisa menulis dan membaca tetapi kemampuan JO,CK dan DK dalam memahami bahasa tulis dalam komunikasi verbal masih kurang karena belum memahami tanda baca dengan baik. dan orang tua dari JO,CK dan DK sudah terbiasa menerapkan metode floor time walaupun orang tua JO,CK dan DK tidak paham pengertian dari metode floor time.

Tidak hanya guru kelas yeng menerapkan pendekatan tersebut dan orang tua JO,CK dan DK terbiasa menerapkan pendekatan floor time yang didalam penerapannya lebih ke komunikasi yang terdiri dari 8 point. Hasil dari penerapan floor time yang diterapkan oleh orang tua JO,CK dan DK membuahkan hasil dalam perkembanganperkembangan emosi, pergaulan, komunikasi dan interaksi JO,CK dan DK saat berada dirumah.

\section{SIMPULAN}

Dalam penerapan pendekatan pembelajaran anak autis dengan metode floor time yang mencakup 5 strategi yang diterapkan oleh guru sehingga banyak membuahkan hasil perkembanganperkembangan yang terjadi pada siswa autis.Berdasarkan pada hasil wawancara dengan guru kelas ditemukan bahwa dalam penerapan metode floor time dapat meningkatkan kemampuan verbal JO,CK dan DK dalam bahasa komunikasi yang ditandai dengan beberapa perkembangan yaitu yang menitik beratkan dalam komunikasi sehingga dalam berbicara $\mathrm{JO}, \mathrm{CK}$ dan DK sudah lumayan jelas dan kemampuan dalam menulis pun sudah 
baik hanya saja butuh arahan dalam menyelesaikan tugas sekolah, walaupun dalam memahami bahasa tulis masih memerlukan bimbingan.

Tidak hanya guru kelas yeng menerapkan pendekatan tersebut tetapi orang tua JO,CK dan DK menerapkan metode floor time yang didalam penerapannya lebih ke komunikasi yang terdiri dari 8 point. Hasil dari penerapan metode floor time yang diterapkan oleh orang tua JO,CK dan DK membuahkan hasil dalam perkembangan-perkembangan emosi, komunikasi dan interaksi dengan lingkungan sekitarnya.

\section{DAFTAR PUSTAKA}

Burgin, B. (2001). Metodologi Pendidikan Kualitatif. Jakarta: Raja Grafindo Persada.

Greenspan, S., Wieder, \& Serena. (2010). Enganging Autism: Melangkah Bersama Autisme. Jakarta: Yayasan Ayo Main.

Handojo, Y. (2004). Autism Petunjuk Praktis dan Pedoman Praktis Untuk Mengajar Anak Normal, Autis dan Perilaku Lain. Jakarta : Buana Ilmu Popular Kelompok Gramedia.

Irwanto, S., \& Rudy. (2011). Austime Dari A Sampai Z: Edisi Khusus Majalah AnakSpesial. Jakarta: CV. Anak Spesial Mandiri.

Kurnia, A. (2007). Pengembangan Metode Pembelajaran Anak Autis Dengan Menggunakan Pendekatan Eksploratif. Tidak Dipublikasikan. PKM. Malang: Universitas Negeri Malang.

Maulana, M. (2007). Anak Autis. Yogyakarta: Kata Hati.

Mulyana, D. (2012). Ilmu komunikasi Suatu Pengantar. Bandung: PT. Remaja Rosdakarya.

Natawidjaja, R \& Alimin Z. (1996), Penelitian Bagi Guru Pendidikan Luar Biasa, Jakarta: Depdikbud Dirjen Dikti.
Nevid, Jeffrey S., Rathus, Spencer A., Greene, \& Beverly. (2003). Psikologi AbnormalEdisiKelima Jilid 2. Jakarta: Erlangga.

Pamuji. (2007). Model Terapi Terpadu Bagi Anak Autis. Jakarta: Departemen Pendidikan Nasional.

Santrock, W. John. 1995. Life-Span Developmental: Perkembangan Masa Hidup. Jakarta: Erlangga.

Stanley I, G. 2006. The Child With Special Needs: Anak Berkebutuhan Khusus. Jakarta: Yayasan Ayo Main.

Surfas, Sean. 2004. The Developmental, Individual Difference, Relationship Based "DIR" Therapy With Older Students With Severe Developmental Disabilities including Autism.

Suwarsih Madya, (2006), Teori dan Praktek Penelitian Tindakan Kelas (Action Research), Bandung, Alfabeta

Soetjiningsih \& Ranuh, IG. N Gede. 1995. Tumbuh Kembang Anak. Jakarta: Penerbit Buku Kedokteran EGC.

Yosfan Azwandi. (2005). Mengenal dan Membantu Penyandang Autisme. Jakarta: Direktorat Pembinaan Tenaga Kependidikan dan Ketenagaan Perguruan Tinggi 